\title{
Kanatlı hayvanlarda mukozal bağışıklık
}

\author{
Zeynep Şık ${ }^{1}$ (0) \\ 1.Veteriner Kontrol Merkez Araştırma Enstitüsü Müdürlüğ̈̈, Ankara
}

Geliş Tarihi / Received: 02.10.2019, Kabul Tarihi / Accepted: 20.05.2020

\begin{abstract}
Özet: Antijenler vücuda mukozal alanlardan girer. Enfeksiyonlar mukozalarda oluşur ve yayılır. Mukozal lenfoid dokular (MALT), spesifik ve nonspesifik bağışıklığı birlikte uyararak antijenleri giriş yerinde yok ederler ve antijenin yayılmasını engeller. Kanatlı hayvanlar sindirim (GALT), solunum (Harderian bez, CALT, NALT, BALT) ve genital sistemde bulunan mukozal lenfoid dokuları ile gelişmiş bir mukozal bağışıklık sistemine sahiptir. Ancak kanatı hayvanların mukozal lenfoid dokularının özellikleri ve savunma mekanizmalarına dair sınırlı bilgi vardır. Bu derleme kanatlı hayvanlarda bulunan mukozal lenfoid dokuları birlikte sunarak enfeksiyonların önlenmesindeki rolüne ve yeni mukozal aşı stratejileri geliştirilmesine katkıda bulunacaktır.
\end{abstract}

Anahtar kelimeler: BALT, CALT, GALT, Kanatlı, NALT

\section{Mucosal immunity in poultry}

\begin{abstract}
Antigens enter the body throught the mucosal surfaces. Infections occur and spread in mucosal surfaces. Mucosal lymphoid tissues (MALT), prevent specific and nonspecific immunity from spreading the antigens at the site of introduction by stimulating together. Poultry animals have a mucosal immune system developed with digestion (GALT), respiratory (Harderian gland, CALT, NALT, BALT) and mucosal lymphoid tissues found in the genital system. However, there are limited information about the properties and defense mechanisms of mucosal lymphoid tissues of poultry. This review will contribute to the role of prevention of infections and the development of novel mucosal vaccine strategies by presenting mucosal lymphoid tissues in poultry.
\end{abstract}

Key words: BALT, CALT, GALT, NALT, Poultry

\section{Giriş}

Kanatlı hayvanlarda bağışıklık sisteminin gelişimi, performans ve hayvanların yaşama gücü ile direkt ilişkilidir. Kanatlı hayvanlarda bağışıklık sistemi hızlı gelişir. Özellikle eti için yetiştirilen tavukların yaşama süresinin kısa olması, bağışıklık sisteminin gelişiminin izlenmesini zorunlu kılar. İmmun sistem üzerine olumsuz etki yapan faktörler nedeniyle oluşan immunsupresyon, hastalıklara karşı kanatılıarın duyarlılığını artırır. Bu durum kanatlı hayvanların yaşama gücünü ve performans hedeflerini olumsuz etkilemektedir. Dünyada kanatlı eti üretiminin, tüm etler içinde en yüksek düzeyde olması nedeniyle kanatlı hayvanların bağışıklık sisteminin yapısı ve gelişimi iyi değerlendirilmelidir (Kaiser 2010, 2012). Kanatlı hayvan ürünlerinin tüketilmesiyle insanlara bulaşan Avian Influenza (Kuş gribi), Salmonella spp., ve Campylobacter enfeksiyonları büyük bir halk sağlığı sorunu oluşturur. Ayrıca hastalıkların tedavisinde kullanılan antibiyotikler yumurta ve ette kalıntı bırakır ve bu ürünlerin de tüketilmesi insan sağlığını tehdit eder. Aynı zamanda antibiyotiklerin kullanımı ile gıda kaynaklı patojenlere karşı direncin ortaya çıkması ve yayılması ile ilgili endişelerin artması sonucunda antibiyotik kullanımında sınırlamalara yol açmıştır. Mevcut kontrol önlemlerindeki sınırlamalar nedeniyle araştırmacıları yeni aşı stratejileri ve alternatif kontrol önlemleri geliştirmeye yöneltmiştir (Jawale ve Lee 2014; Kang ve ark. 2014; Gayet ve ark. 2017; Kumar ve ark. 2018).

Kanatı hayvan üretiminde en önemli sorunlarından biri; hızlı bulaşan hastalıklardır. Kanatlı hayvanlarda bu hastalıkların neden olduğu kayıplar esas olarak aşılamalar ile azaltılabilmektedir. Aşılamalar ile uzun süreli bağışıklık ve koruma sağlanabilir. Özellikle kümes hayvanları üretiminde önemli ekonomik kayıplara yol açan infeksiyöz bronşit (IB) virüsü gibi viral enfeksiyonlar mukozal yoldan yapılan aşılamalar ile kontrol edilebilir (Kang ve ark. 2014; De Geus ve ark. 2015). Mukozal aşıların geliştirilme çalışmalarında mukozal yüzeylerin hedeflenmesinin nedeni, mukozal alanlar patojenlerin giriş yerleri olmasıdır. Enfeksiyonlar mukozalarda oluşur ve yayılır (Yılmaz ve ark. 1995). Mukozal lenfoid dokuların en önemli görevi patojenleri giriş yerinde yok etmek ve enfeksiyonların yayılmasını önlemektir (Lillehoj ve Lillehoj 2000). Mukozal lenfoid dokuların önemli özelliklerinden biri de; spesifik ve nonspesifik bağı- 
şıklığı birlikte uyarabilmesidir. Spesifik bağışıklığın uyarılması uzun süre immunolojik belleğin oluşması demektir. Bu özelliğin kazanımlarından biri de herhangi bir mukozal yüzeyden aşı uygulaması yapıldığı zaman bu bölgeye en uzak mukozal dokuyu bile uyarabilmesidir (Saatçi ve Bozkır 2003).

Mukozal alanlarda gelişen konakçı bağışıklık yanıtlarının enfeksiyonların kontrolünde önemli rol oynadığından dolayı bu bölgedeki immunolojik olayları anlamak zorunludur (Amarasinghea ve ark. 2018). Kanatlı hayvanlarda mukozal lenfoid dokular arasında en çok solunum sisteminde bulunan lenfoid dokular çalışılmıştır. Solunum sistemi lenfoid dokuları arasında da en çok Harderian bez ve nazal ilişkili lenfoid doku çalışılmıştır. Nazal ilişkili lenfoid doku hem doğal enfeksiyonlarda hem de aşılamalarda immun yanıtlar için temel indüktif alan olarak kabul edilir. Çünkü aşı uygulamalarında burun boşluğu kolayca erişilebilir, oral uygulamalar ile karşılaştırıldığında düşük seviyede proteolitik enzimlere sahip olması ve yüksek derecede vaskülarize epitel tabakası ve bol lenfosit içeren geniş yüzey alanı ile aşı uygulamaları için en cazip yer oluşturmaktadır (Kang ve ark. 2013,2014; De Geus ve ark. 2015). Özellikle kanatlı hayvanlarda sindirim sisteminde bulunan bağırsak ilişkili lenfoid doku bölümlerinin histolojik yapısı hakkında birçok literatür bulunur iken immunolojik savunma mekanizması ve özelliklerine dair az sayıda literatür vardır. Bağırsak ilişkili lenfoid doku daha çok insanlarda kapsamlı olarak araştırılmıştır.

\section{Kanatlı Hayvanlarda Mukozal Bağışıklık (MALT)}

Mukozal yüzeyler patojenlerin giriş yolu olduğu için sürekli patojenlerle karşılaşırlar ve bu yüzden mukozal bağışıklık, ilk savunmada önemlidir (Lamichhane ve ark. 2014). Yoğun musin tabakası, antimikrobial peptitler, sıkı bağlantılı (tight junction) proteinleri üreterek epitel hücreleri mukozal alanları korur (Kunisawa ve ark. 2012).

Lenfositler bağışıklık sisteminin önemli bileşenleridir ve tüm mukozal dokuların yüzeyleri boyunca yer alan mukozal lenfoid doku yaklaşık \%50 oranında lenfosit bulunur. MALT'ta bulunan immun sistem hücreleri; dendritik hücreler (DC), makrofajlar, T ve B lenfositleridir (Zhao ve ark. 2016). Mukozal lenfoid dokuların üzerini örten özelleşmiş $M$ hücreleri (Mebranöz epitel hücresi) lumenden antijenleri alıp taşımasıyla ya da antijen sunan dendritik hücreler (APC) tarafından naif $T$ ve $B$ lenfositlerini uyarır (Pavot ve ark. 2012). Uyarılan T hücre alt sınıflarl; sitotoksik $\mathrm{CD}^{+} \mathrm{T}$ hücreleri hasara uğramış konakçı hücrelerini yok eder ve $\mathrm{CD} 4^{+} \mathrm{T}$ hücreleri ise; istilacı patojenleri yok ederek hücresel bağışıkığı uyarır (De Geus 2012). Antijene özgü etkileşimlerin bir sonucu olarak T hücreleri ve IgA ile ilişkili sitokin ailesi ( TGF- $B$, IL-2, IL-4, IL-5, IL-6, IL-10), germinal merkezde ve $B$ hücrelerinde IgA sınıf değişimini destekler (Lamichhane ve ark. 2014). B hücrelerinde üretilen tek J zincirli dimerik IgA, mukozal epitel hücrelerinin bazolateral yüzeyinde bulunan polimerik immunglobulin reseptörüne (plgR) bağlanır ve sonra transsitoz ile mukozaya salınır. Transsitoz esnasında plgR'nin bir kısmı ayrılırken bir kısmı da dimerik IgA'nın Fc bölümüne bağlı kalır ve salgı bileşenini (slgA) oluşturur. Sistemik dolaşımda IgA (monomerik ya da polimerik) yapısında bulunmaz (Shakya ve ark. 2016). IgA ${ }^{+}$, yüksek sentez hızı ve mukozal epitelyum boyunca taşınabilme yeteneğiyle (Withanage ve ark. 1997) sindirim ve solunum sistemi mukozası sekresyonunda temel izotiptir. $\operatorname{lgG} \mathrm{G}^{+}\left(\lg ^{+}\right)$, kanda ve hücre dışı sıvıların temel izotipidir. $\operatorname{lgG}^{+}$, fagositozun ve komplement sistemin uyarılmasıyla patojenleri opsonize eder ve yutar. $\lg \mathrm{A}^{+}$, fagositlerin olmadığ bölgelerde çalışarak hem nötralizasyonu sağlar hem de adezyonu engeller (Pavot ve ark. 2012).

\section{Sindirim Sisteminde Mukozal bağışıklık (GALT)}

Sindirim yolu mukozası fiziksel ve biyolojik bariyerlere sahip olmasına rağmen birçok patojen mikroorganizmalar için giriş kapısıdır (Kunisawa ve ark. 2012). Bağırsak epitel hücreleri; bakteri ve viral antijenleri patojen ilişkili moleküler modeller (PAMP) tarafından tanınarak tehlike sinyalleri nükleotit bağlayıc oligomerizasyon ailesi, Toll benzeri reseptörler (TLR) gibi patojen tanıma reseptörleri (PRR) aracılığıyla (Davison ve ark. 2008; Pavot ve ark. 2012), nükleer faktör $K B$ (NF- $K B$ ) aktive edilen intraselüler yollar ile sitokinler, interferon gama (IFN- $\gamma$ ) ve tümör nekrozis alfa (TNF- $\alpha$ ) salınmasını sağlar (Gayet ve ark. 2017; Kumar ve ark. 2018). Shira ve Friedman (2018); civciv bağırsak epitel hücrelerinin bakteriyal antijenlerin (LPS ve LTA) TLR'leri uyarmadan proenflamatuvar sitokinler IL-6 ve IL-18 salgıladığını bildirmiştir. Mukozal bariyerler epitel tabakasını korur ancak patojen mikroorganizmalar; bazolateral yüzeylerde özel bir epitelyum içinde yer alan $M$ hücrelerinin adezyon ve invazyona uğramasıyla aktin polimerazasyon oluşumunun sonucunda yutulur. Sınırsız patojen invazyonuna uğrayan epitel doku bozulur ve açוlır. Epitel dokusunun bozulmasıyla patojenler bağırsak lümenine yerleşirler (Gayet ve ark. 2017; Kimura 2018). M hücreleri tarafından taşınan ve transitosise uğramış antijenler bazal membranın altında bulunan dendritik hücreler ve makrofajlar gibi antijen sunan hücreler tarafından işlenerek antijenik peptidleri $B$ ve $T$ hücrelerine sunularak len- 
foid dokulara taşınır (Davison ve ark. 2008; Shakya ve ark. 2016). GALT'ın lenfoid dokularında bulunan T lenfositleri; naif T hücreleri ile IFN-gama üreten Th1 hücreleri, IL-4 ve IL-10 üreten Th2 hücreleri antijenleri yok ederler ve B lenfositlerinin IgA sınıf değişimi desteklerler (Kunisawa ve ark. 2012; Kumar ve ark. 2018).

\section{Farengeyal Tonsiller}

Lenfoid dokunun; lenfoid hücreleri ve folikülleri nazofarenkse yerleşmiştir. Kanatlı hayvanlarda koanal ve infundibular yarıklar etrafında bulunan bu doku kriptlerden yoksundur (Casteleyn ve ark. 2010).

\section{Özefageyal Tonsiller}

Memelilerde bulunmayan, kanatlılarda özefagus ile proventriculus bağlantısına yerleşmiş olan özefageyal tonsil; ince fibröz bir kapsülle çevrilmiş 6-8 birimden meydana gelen tonsil kriptlerinden oluşur (Aytürk 2008). Kriptler; lenfoepitelyumu oluşturur. Lenfo epitelyum; T lenfositleri, plazma hücreleri, makrofaj ve dendritik hücreler birlikte lenfoid dokuyu oluşturur (Çolakoğlu ve Dönmez 2018). Özefageyal tonsiller, Peyer Plakları gibi B hücrelerinin gelişimine ve çoğalmasına katkı sağlar (Davison ve ark. 2008).

\section{Proventriküler Lenfoid Doku}

T lenfositleri çoğunlukla mukozal dokunun lamina probriasında bulunur. T lenfositleri merkezde, bezsel kanallar ve proventriküler lümende; B lenfositleri periferal bölgelere; proventriküler bezlerin dip kısmında yerleşmiştir (Casteleyn ve ark. 2010).

\section{Pilorik Tonsil}

Midenin sadece antimezenterik tarafinda yer alan lenfoid doku; 15-20 adet tonsilden oluşur. Duedonum Lieberkühn kriplerini lenfoepitelyal alanlar tarafından tonsil kriptlerine dönüştürür. Kript alanlarını örten epitel hücreleri arasında $\mathrm{M}$ hücreleri vardır. B hücreleri germinal merkezde, CD3 T hücreleri interfoliküler bölgede, CD45 ${ }^{+}$hem interfoliküler hem de germinal merkezde bulunur (Nagy ve Olah 2007).

\section{Meckel Divertikülü}

Embriyonik dönemde vitellüs kesesinin bağırsak kanalına bağlanan sap kısmının yumurtadan çıktıktan sonra oluşan yaşam boyu kalıntısıdır (Lillehoj ve Trout 1996). Kuluçka döneminde Meckel divertikülünde; hiç lenfoid hücre bulunmazken kuluçkadan sonra ilk ikinci haftasında miyeloid doku görülmeye başlar. Tek $\mathrm{CD}^{4} 5^{+}$hücreleri bağ doku ve epitelyum hücrelerine bulunur (Davison ve ark. 2008). Yoğun germinal merkez şekillenmesi 5-7. haftalarda oluşmaktadır. Germinal merkezde B hücreleri ve makrofajlar bulunur iken $T$ hücreleri germinal merkeze komşu olarak yerleşmiş̧ir (Aytürk 2008; Lillehoj ve Trout 1996).

\section{Peyer Plakları}

Tavuklarda jejunumun antimezenterik tarafına yerleşmiştir. İleosekal bağlantının 5 ile $10 \mathrm{~cm}$ yukarısında yer alır (Casteleyn ve ark. 2010). Peyer Plaklarının sayıları, 10 günlük yaşta 1 iken 16 haftalıkta en fazla 6'ya yükselir, en yaşlılarında (58 haftalık) 1 tane bulunur (Befus ve ark. 1980). Barsak lümeninde kalınlaşmış villuslar ve foliküler bir yapı sahip olan Peyer plakları M hücrelerini bulundurur (Kimura 2018). Subepitelyal alanlarda; B hücrelerine bağlı makrofajlar bulunur. İnterfoliküler alanlarda neredeyse tüm $T$ hücreleri ve TCR $\alpha \beta_{1}$ ile $C D 4^{+}$çoğunlukta bulunur. Germinal merkez ve interfoliküler alanlarda; çoğunlukla $\lg \mathrm{Y}^{+}$plazma hücresi ile birkaç $\lg \mathrm{A}^{+}$ve $\operatorname{lgM}^{+}$ plazma hücreleri bulunur. Epitelin lümeninde $\lg \mathrm{A}^{+}$ ve $\lg \mathrm{Y}^{+}$bulurken $\lg \mathrm{M}^{+}$yoktur (Davison ve ark. 2008).

\section{Sekal Tonsiller}

Sekal tonsiller anatomik olarak her iki sekumun rektuma geçiş duvarının medialine (Casteleyn ve ark. 2010) veya ileosekal bağlantıya yerleşir. Lenfositlerin \%45-55'i B hücrelerinden \%35'i T hücrelerinden oluşur (Lillehoj ve Lillehoj 2000). Sekal tonsillerin immun sistem hücreleri subepitheliyal alanlarda; çoğunlukla chB6 ${ }^{+}, \lg \mathrm{M}^{+} \mathrm{B}$ hücreleri, $\lg \mathrm{Y}^{+} \mathrm{B}$ hücresi, nadir olarak $\lg \mathrm{M}^{+}$ve $\lg \mathrm{A}^{+}$plazama hücreleri birkaç $\mathrm{CD}^{+}$ve $\mathrm{CD} 8^{+} \mathrm{T}$ hücreleri bulunur (Davison ve ark. 2008). Germinal merkezde; T ve B hücreleri, $\operatorname{lgM}^{+}$ $\lg \mathrm{A}^{+}, \lg \mathrm{Y}^{+}$plazma hücreleri bulunur (Lillehoj ve Trout 1996). Tavukların sekal tonsillerinde özelleşmiş $M$ hücreleri bulunur (Kitagawa ve ark. 2003). Sekal tonsiller kuluçkadan sonra 10. günde kolaylıkla tespit edilebilir. Kanatılıar yaşları ilerledikçe Peyer plakları ve sekal tonsiller daha az belirginleşir ve sayıları azaIır (Lillehoj ve Trout 1996 ).

\section{Bursa Fabricius}

Kanatıların primer lenfoid organı olan bursa Fabricius, esas B lenfositlerinin gelişmesinden ve çoğalmasından sorumludur. Yaklaşık olarak 10.000 lenfatik folikül içerir (Kozuka ve ark. 2010). Antijenlerin alınmasını ve örneklenmesini sağlar. T lenfositlerini bulundurur bu özelliği ile sekonder lenfoid organ olarak görev yapar (Davison ve ark. 2008). 


\section{Solunum Sisteminde Mukozal Bağışıklık}

Solunum sistemi yoluyla vücuda giren antijenler uzun süreli bir uyarıma ihtiyaç duymadan nonspesifik bağışıklık elemanları tarafından tespit edilir ve yok edilirler (Tamura ve Kurata 2004). Epitel hücreleri antijenleri, patojen tanıma reseptörleri ve Toll benzeri reseptörler ile tespit ederler (Crane ve ark. 2018). Bu hücreler tarafından tanınan antijenler, makrofajlar ve dendritik hücreler aracılığıyla nonspesifik bağışıklığı uyarırlar (Tamura ve Kurata 2004). Nonspesifik bağışıklıkta rolü olan hücreler ve moleküller; fonksiyonlarını tek başlarına yürütebilmelerine rağmen (Diker 2005) makrofaj ve dendritik hücreler tarafından alınıp işlenen antijenler, MHC hücreleri üzerinde solunum sisteminde bulunan lenfoid dokulara; konjunktival lenfoid doku, Harderian bez, nazal lenfoid doku ve bronş ilişkili lenfoid doku sunularak immun yanıtı başlatırlar (De Geus ve ark. 2015).

Kanatlı hayvanların solunum yolu mukozası memelilerden daha az serbest yaşayan makrofajları bulundurmasına rağmen büyük bir makrofaj ve dendritik hücre ağına sahiptir (De Geus ve Vervelde 2013). Kanatlı hayvanların akciğerlerindeki makrofajlar; atriumun epitel alanlarında, tersiyer bronşların infundibulasının epitelinde ayrıca bağ dokusunda bol miktarda bulunur (Smialek ve ark. 2011). Makrofajlar partikülleri uzaklaştırır ve istilacı patojenleri ortadan kaldırımasında etkin rol oynar (Mutua ve ark. 2016). Kanatlı hayvanlarda, memelilerde bulunan alveolar makrofajlar olmadığından dolayı heterofiller, solunum sistemi savunmasında önemli rol oynar (Fagerland ve Arp 1993). Dendritik hücreler ise nazal boşluklar boyunca yaygındır. Antijenleri ve partikülleri izler çünkü nazal mukozalarda ilk antijen alımını DC'ler gerçekleştirir (Qin ve ark. 2015). Hava yolu DC'leri ise; işledikleri antijenleri doğrudan hava yolu lümenine verir ve böylece lümen yüzeyindeki antijenler sürekli olarak örneklenir (De Geus 2012). DC'ler, IgA sentezlenmesini uyarır (De Geus ve ark. 2015). slgA, antijenlerin invazyon ve kolonizasyonunu engelleyerek mukozal epitel yüzeylerin korunmasında sağlar (Ansari ve ark. 2016). Aynı zamanda slgA, immun yanıtın yayılmasında önemli rol oynar (Fan ve ark. 2015).

\section{Harderian Bez}

Kanatlı türleri arasında yerleşim yeri çok az farklılık gösterir. Bazı kanatlı türlerinde, göz küresinin daha çok anteriyoruna yerleşirken, Harderian bez genellikle göz küresinin ventromediyaline ve kasların altındaki periorbital bağdokuya yerleşmiştir (Kozlu ve Altunay 2010). İmmunolojik savunmada önemli bir rolü olan Harderian bezin, temel görevi goblet hüc- releri tarafından mukus ve müsin salgılamasıyla; gözün ve membrana niktitansın yağlanması ve temizlenmesini sağlar (Krunkosky ve ark.2018). Harderian bez; embriyonik dönemin 11. ve 12. günleri arasında konjuktivanın koni şeklindeki epitel hücrelerinden köken alarak gelişir (Maslak 1994). Kanatılıarda Harderian bezin subepitelyal bölgede; plazma hücreleri, interfoliküler bölgelerde; T hücreleri, dendritik hücre benzeri yapılar ve makrofajlar bulunur (Nochi ve ark. 2018). Tek ya da küçük gruplar halinde bulunan CD45+ lökositleri; chB6+ B hücresi, makrofajlar ve heterofilleri içerir. Harderian bezde bulunan çoğunluktaki T hücreleri; $C D 4^{+}$ve TCR $\alpha \beta_{1}{ }^{+}$ile $\mathrm{CD}^{+}$ TCR $\gamma \delta^{+}$T hücreleridir (Davison ve ark. 2008). Plazma hücreleri, embriyonik dönemin 17. gününden başlayarak kuluçka sonrası 30. güne kadar gelişimi devam eder ve plazma hücrelerinin sayısı artar (Maslak 1994). Harderian bezde sentezlenen immunglobulin sınıfları oranıyla ilgili farklı görüşler vardır. Olah ve ark. (1992) Harderian bezde, 8-10 haftalık tavuklarda plazma hücreleri; $\operatorname{lgM}^{+}$ve $\operatorname{lgA}^{+}$çok sayıda iken $\mathrm{IgY}^{+{ }^{\prime}}$ nin çok az sayıda olduğunu bildirirken; Ohshima ve Hiramatsu (2002) 5 haftalık tavuklarda $\lg \mathrm{Y}^{+}$plazma hücresinin, $\lg ^{+}$ve $\operatorname{lgA}^{+}$plazma hücresinden daha yaygın olduğunu bildirmişlerdir. İmmunglobulin sınıfları arasındaki farklı sonuçlara; yaş, çevresel antijenler, stres ya da Harderian bezin hiç uyarılmamış olması, etkili olabilir (Ohshima ve Hiramatsu 2002).

\section{Konjunktival Lenfoid Doku (CALT)}

Konjunktival lenfoid doku; tavuklarda (Fix ve Arp 1991) ve hindilerde (Fix ve Arp 1989) alt ve üst göz kapağının kıvrımlarında gözlenmiştir. Tavuklarda germinal merkez kuluçka sonrası 2. haftaya kadar gelişirken, hindilerde kuluçka sonrası 19. güne kadar oluşur (Fix ve Arp 1989,1991). Gözyaşı sıvısında bulunan sitokinler, antimikrobiyal peptitler ve slgA ile beraber ilk savunma hattını oluşturarak mukozal bağışıklıkta önemli rol oynar (Lamichhane ve ark. 2014). Plazma hücreleri kuluçka sonrası 4. haftada gözlenir (Fix ve Arp 1991). Konjuntival lenfoid doku $B$ hücrelerinin yanı sıra önemli bir T hücre populasyonuna sahiptir. T hücrelerinin yaklasık \%37'si; \%16.5 CD4 ${ }^{+}$T hücresi, \%6 CD8ß ${ }^{+} \mathrm{T}$ hücresi, \%6 $\gamma \delta^{+} \mathrm{T}$ hücrelerinden oluşur (Van Ginkel ve ark. 2012). Bu T hücre alt grupları, TCR $\alpha \beta_{1}{ }^{+} \mathrm{T}$ hücreleri, humoral bağışıklıkta rol oynayan; $\lg A^{+} B$ hücreleri ile birkaç $\lg Y^{+}$ ve $\operatorname{lgM}^{+}$B hücresi bulunur (Gurjar 2013).

\section{Nazal Lenfoid Doku (NALT)}

Nazal boşlukların mukozalarında bulunan nazal lenfoid doku; tavuklarda septum nasalenin dip kısmı ile her iki koanal yarığın dorsaline dağılan iki lenfoid fo- 
likülden oluşur. Kuluçka sonrası oluşan NALT, 7 günlük civcivlerde gözlenir fakat lenfatik yapı olgunlaşmamıştır. 14 günlük civcivlerde lenfoid doku gelişir, lenfositlerin sayısı artar ve sekonder lenfoid foliküller ortaya çıkar. 35 günlük tavuklarda NALT temel gelişimini tamamlar (Kang ve ark. 2013). Ördeklerde ise; nazal boşluğun kaudalinde iki çift lenfoid doku vardır. Bir çifti koanal yarığın dorsalinde, diğer çifti septum nasalenin iki tarafında bulunur (Kang ve ark. 2014). Nazal mukozanın savunmasında rol oynayan lenfositler; tavuklarda paranasal (nasolakrimal kanallar, lateral nazal bezler ve onların kanalları) organlara, nazal boşluklara, respiratorik epitel ile olfaktorik bölgelerin nazal mukozasına dağılmıştır (Ohshima ve Hiramatsu 2000). Dağınık lenfoid dokular nazal mukozanın lamina probriası ve epitelinde $\mathrm{CD}^{+} \mathrm{T}$ hücreleri (Sepahi ve Salinas 2016) ve immunglobulin üreten $B$ hücreleri bulunur. B hücrelerinin çoğunluğunu $\lg \mathrm{Y}^{+}$hücreleri oluştururken (Nochi ve ark. 2018), $\lg \mathrm{A}^{+}$ve $\lg \mathrm{M}^{+}$hücreleri daha seyrektir. Nazal bezlerin akıtıcı kanallarında ve özellikle oral boşluklarda çok sayıda $\mathrm{CD} 8^{+} \mathrm{T}$ hücreleri bulunurken, sadece birkaç immunglobulin hücreleri vardır. Bu durum NALT'ın bir T hücresi olduğunu ve $C D 8^{+} \mathrm{T}$ hücrelerinin üst solunum yolları savunmasında önemli rolü olduğunu gösteriyor (Ohshima ve Hiramatsu 2000). Lenfoid hücrelerin geniş alanlara dağılmış olması NALT'ın antijen tanıma ve antijen sunan hücrelerinin daha etkin çalışmasını sağlar (Kang ve ark. 2014). Tavuk NALT'ının lenfoid nodülleri $\mathrm{CD}^{+}{ }^{+} \mathrm{T}$ hücreleri ile çevrilmiş gelişmiş bir germinal merkezle ile $B$ hücrelerinden oluşur (Ohshima ve Hiramatsu 2000; Sepahi ve Salinas 2016). NALT'ın hücresel immun yanıtta daha etkin olmasını, lenfoid nodülleri kolonize eden $\mathrm{CD}^{+}{ }^{+} \mathrm{T}$ hücreleri sayısındaki artıştan kaynaklanmaktadır (Krunkosky ve ark. 2018).

\section{Trakea}

Kanatlı hayvanlarda trakea gerçek bir lenfoid doku olarak tanımlanmamasına rağmen antijenlere karşı güçlü bir immun yanıt oluşturur (De Geus ve ark. 2012). Özellikle mikoplazma enfeksiyonlarında trakeanın mukozasında $\mathrm{CD} 8^{+} \mathrm{T}$ hücreleri folikül benzeri kümeler oluşturken, $\mathrm{CD} 4^{+} \mathrm{T}$ hücreleri dağınık dağılmıştır (Gaunson ve ark. 2000). Javed ve ark. (2005) aşılanmış ve aşılanmamış tavuklarda Mycoplasma gallisepticum enfeksiyonunda trakea mukozasının bağışıklık yanıtı karşılaştırılmıştır. Aşılanmış tavuklarda $\operatorname{lgG}{ }^{+}$ve $\lg \mathrm{A}^{+}$sentezleyen plazma hücrelerinde önemli artışlar gözlenmiştir. Trakeanın diğer lenfoid organlarla bağışıklık yanıtının karşılaştııılığında farklı sonuçların elde edilmesinin sebebi; trakeadaki mukozal doku miktarının az ve kıkırdak dokusunun fazla olmasından kaynaklanır (Amarasinghea ve ark. 2018).

\section{Bronş ílişkili Lenfoid Doku (BALT)}

Kanatı hayvanların akciğerleri, iyi organize olmuş lenfoid yapılara ve diffüz dağılmış lenfoid ve miyeloid hücrelere sahiptir (Davison ve ark. 2008). Bu lenfoid doku primer bronşlarda ve sekonder bronşların başlangıcına yerleşmiştir. Hindi ve tavuklarda yerleşim yerleri benzerdir (Fagerland ve Arp 1993). Hindilerde tavuklara göre lenfoid doku daha geniş bir dağılım gösterir (Reese ve ark. 2006). Bronş ilişkili lenfoid dokunun gelişimi yaşa ve antijen uyarımına bağlıdır (Nochi ve ark.2018). Kuluçkadan sonra CD45+ lökositleri sayısı artar ve primer bronşa göçü başlar daha sonra sekonder bronşun başlangıcında lenfosit infiltrasyonu başlar (Fagerland ve Arp 1993; Reese ve ark. 2006). Olgun plazma hücreleri ve B lenfositleri ilk kez 2 haftalık yaşta gözlenmiştir. T hücreleri 1 haftalık yaşta BALT epitelinin altında bulunur. CB3+ hücreleri 2 haftalık yaşa kadar BALT nodülünde bulunur (Fagerland ve Arp 1993-b). Germinal merkezler, 2-4 haftalık yaşta oluşur ve kanatlı BALT'ının belirgin ve tutarlı bir özelliğidir (Fagerland 1992). CD4+ T hücre germinal merkezin parafoliküler kapaklarda bulunur. $\mathrm{CB}^{+} \mathrm{B}$ lenfositlerinin dağılımıyla örtüşür. $\mathrm{CD}^{+} \mathrm{T}$ hücreleri ise tüm dokulara dağılmıştır (Fagerland ve Arp 1993-b). Germinal merkezde dendritik hücre foliküllerine benzeyen uzun sitoplazmik çıkıntıları olan IgM ve IgY hücreleri bulunur (Reese ve ark. 2006). Lenfoid nodüllerde germinal merkezin bulunması humoral immun yanıtın var olduğunu gösterir (Liu ve ark. 1992). BALT'ın yapısı, farklı epitelyal ve lenfositik bölümleriyle timusu andırır (Fagerland 1992).

\section{Genital Sistemde Mukozal Bağışıklık}

Kanatlı hayvanlarda dişi genital organlar ovaryum ile başlar ve oviduct ile devam eder ve kloaka'ya açılarak son bulur (Dursun 2006). Oviduct, yumurta oluşumunun bütün aşamalarının gerçekleştiği önemli bir organ olduğundan dolayı H9N2 avian influenza virüs (Wang ve ark. 2015), avian infeksiyöz bronşit virüs (Nii ve ark. 2015), Newcastle hastalığı virüsü (Rauw ve ark. 2017), Salmonella Enteritidis (Anastasiadou ve Michailidis 2016), Salmonella Pullorum (Wigley ve ark. 2015) ve Salmonella Typhimurium gibi etkenlerin oviduct dokusuna hasar vermesiyle yumurta veriminde düşme, yumurta kabuk yapısı ve kalitesinin bozulması ile kontamine yumurta üretilmesine neden olurlar (Withanage ve ark. 1997). Özellikle kontamine yumurta, insanlarda gıda zehirlenmesine neden olan Salmonella Enteritidis enfeksiyonunun ana kaynağıdır. Bu durum büyük bir halk sağlığı 
sorununu ortaya çıkarır (Johnston ve ark. 2012). Bu patojen mikroorganizmalar kanatlı yetiştiriciliği endüstrisinde büyük ekonomik kayıplara neden olmasına rağmen (Withanage ve ark. 1997; Johnston ve ark. 2012; Rauw ve ark. 2017) dişi üreme sisteminin enfeksiyonlara karşı bağışıklık mekanizmasına dair çok az çalışma vardır (Davison ve ark. 2008).

Kanatlı hayvanların ovaryum ve oviducttunda bulunan lenfoid hücreler ve makrofajların varlığıyla diğer mukozal lenfoid organlardan farklı değildir (Kimijima ve ark. 1990; Withanage ve ark. 2003). Oviductta nonspesifik bağışıklık; Patojen-ïlişkili Moleküler Modelleri, Toll Benzeri Reseptörler tarafından antijenlerin tanınmasıyla başlar. Tavuk oviductunda TLR1-2, -2-1, -2-2, -3,-4,-5,-7,-15,-21 üyeleri bulunurken; ovaryumda TLR2-2 dışındaki oviductaki üyelerin hepsi vardır (Yoshimura 2015). TLR'ler, nükleer faktör $K B$ ve AP-1(c-Fos ve c-Jun) gibi aktive edilen intraselüler yollar ile sitokin ve kemokin genlerinin transkripsiyonel uyarımını sağlar (Yoshimura 2015; Anastasiadou ve Michailidis 2016). Oviduct ve ovaryumda bulunan önemli sitokinler IL-2, IL-4, IL-6, IL-12, IFN- $\gamma$ ve kemokinler CXCLi2, CXCli4 (Johnston ve ark. 2012) üyeleri immun sistem hücrelerini antijenin olduğu bölgeye toplayarak hücresel ve humoral bağışıklığı uyarırlar (Wang ve ark. 2015). Hücresel bağışıklıkta önemli rol oynayan $T$ lenfositleri hem ovaryumda hem de oviductta bulunur (Withanage ve ark. 1997). T lenfositleri ilk kez oviductta 5 haftalık yaşta gözlenmiştir. T lenfositleri sayısı; magnum, isthmus ve uterusta 15 haftalık yaşta iken infundibulum ve vajinada 19 haftalık yaşta zirveye çıkar (Khan ve ark. 1996). CD4 ${ }^{+} T$ lenfositleri çoğunlukla lamina propriasında ve en çok vajinada en az magnumum ve isthmusda bulunur (Withanage ve ark. 1997). CD4+ ${ }^{+}$lenfositleri; Salmonella gibi hücre içi bakterilerin yol açtığı enfeksiyonlarda özel bir öneme sahiptir ve IFN- $\gamma$, TNF- $\alpha$ gibi makrofaj aktive edici sitokinleri üreterek etki eder (Withanage ve ark. 2003; Jawale ve Lee 2014). CD8 ${ }^{+}$T lenfositleri çoğunlukla lamina propria, submukoza, muskularis ve subserozaya dağılmıştır ve çok sayıda vajina, ovaryum ve infundibulumda bulunur (Shakya ve ark. 2016). CD8 ${ }^{+}$ T lenfositleri oviducttaki viral enfeksiyonlara karşı savunmada önemli rol oynar (Wang ve ark. 2015). Sitotoksik hücrelerin, avian infeksiyöz bronşit (IB) virüs enfeksiyonunda isthmus ve uterus mukozasında artışıyla proinflamatuvar sitokinlerin; IL1ß, IL6, IFNy ve IL2 üreterek etki eder (Nii ve ark. 2015).

Tavuklarda B lenfositleri ve immunglobulin sınıfları oviducttun glandüler ve epitel hücrelerinin yüzeyine yerleşmiştir. $\lg \mathrm{Y}^{+}$hücreleri infundibulum, isthmus ve uterusun epitel hücreleri ile magnumun glandüler dokusunda çok sayıda iken $\lg \mathrm{A}^{+}$ve $\lg \mathrm{M}^{+}$ hücrelerinin sayısı magnumun glandüler dokusunda daha fazla olduğunu gözlenmiştir (Kimijima ve ark. 1990). Olgun tavukların ovaryumunda IgA ${ }^{+}$hücreleri az sayıda iken $\lg Y^{+}$hücreleri yoktur. $\operatorname{lgM}^{+}$hücreleri ovaryumun stromasında bulunur (Withanage ve ark. 1997). Bu bulgular oviducttun maternal antikorların yumurtaya taşınmasında önemli rol oynadığını gösteriyor. Yumurtanın sarısında $\lg \mathrm{Y}^{+}$, beyazında $\operatorname{lgM}^{+}$ve $\lg \mathrm{A}^{+}$hücreleri bulunur (Kimijima ve ark. 1990; Withanage ve ark. 1997; Davison ve ark. 2008). Maternal antikor kuluçkadan yeni çıkan civcivlerin bağışıkık sistemi gelişinceye kadar enfeksiyonlara karşı korur (Rauw ve ark. 2017). Salmonella enfeksiyonuna karşı korumada tek başına antikorların varlığı yeterli olmasa da, antikorlar hedef hücreye girmeden önce ve bu patojenin hücreden hücreye yayılması sırasında Salmonella ile etkileşime girer. Anti-Salmonella antikorları opsonizasyonu sağlar böylece makrofajların bakterileri alımını kolaylaştırır (Jawale ve Lee 2014). Makrofajlar, ovaryum foliküllerinde ve oviductta bulunur en sık infundibulum ve vajinada gözlenmiştir (Davison ve ark. 2008; Yoshimura 2015). Kanatlı hayvanların üreme sisteminde enfeksiyonlara karşı savunmada endokrin sistemin de etkisi vardır (Yoshimura 2015). Erkek üreme sistemi enfeksiyonların oluşmasında ya da vertikal bulaşmada daha az etkilidir (Davison ve ark. 2008).

Teşekkür: Bu derlemede makalesinin hazırlanmasında desteğini esirgemeyen danışman hocam sayın Prof. Dr. Mehmet AKAN'a teşekkür ederim.

\section{Kaynaklar}

1- Amarasinghea A, Abdul-Cadera MS, Almatrouk Z, Van Der Meer F, Cork SC, Gomıs S, Abdul-Careem MF. (2018). Induction of innate host responses characterized by production of interleukin (IL)- $1 \beta$ and recruitment of macrophages to the respiratory tract of chickens following infection with infectious bronchitis virus (IBV). Vet Microbiol, 215: 1-10

2- Anastasiadou M, Michailidis G. (2016). Cytokine activation during embryonic development and in hen ovary and vagina during reproductive age and Salmonella infection. Res Vet Sci, 109: 86-93

3- Ansari AR, GE X-H, Huang H-B, Huang X-Y, Zhao X, Peng K-M, Zhong J-M, Liu H-Z. (2016). Effects of lipopolysaccharide on the histomorphology and expression of Toll-like receptor 4 in the chicken trachea and lung. Avian Pathol, 45: 530-537

4- Aytürk (Akar) Ü. (2008). Broylerlerde özefageal tonsillerin ışık mikroskobik yapısı (YL.Tezi), SÜ Sağlık Bilimleri Enstitüsü, Konya

5- Befus AD, Johnston N, Leslie G, Bienenstoc J. (1980). Gut-associated lymphoid tissue in the chicken. I. Morphology, ontogeny, and some functional characteristics of Peyer's patches. J Immunol., 125 : 2626-2632

6- Casteleyn C, Doom M, Lambrechts E, Broeck WV, Cornillie PS, Cornillie P. (2010). Location of gut-associated lymphoid tis- 
sue in the 3-month-old chicken: A review. Avian Pathol., 39: 143-150

7- Crane MJ, Lee KM, Fitzgerald ES, Jamieson AM. (2018). Surviving deadly lung infections: Innate host tolerance mechanisms in the pulmonary system. Front. Immunol, 9: 1421.

8- Çolakoğlu F, Dönmez HH. (2018). Kanatlıların sindirim kanalı lenfoid dokusu. Atatürk Üniversitesi Vet. Bil. Derg, 13:106-111

9- Davison F, Kaspers B, Schat K A eds. (2008). Avian Immunology. London: Academic Press

10- De Geus ED. (2012). Respiratory immune responses in the chicken; Towards development of mucosal avian influenza virus vaccines. [https://dspace.library.uu.nl/handle/1874/240656]

11- De Geus ED, Degen WG, Van Haarlem DA, Schrier C, Broere F, Vervelde L. (2015). Distribution patterns of mucosally applied particles and characterization of the antigen presenting cells. Avian Pathol., 44: 222-229

12- De Geus ED, Rebel JMJ, Vervelde L. (2012-a). Induction of respiratory immune responses in the chicken; implications for development of mucosal avian influenza virus vaccines. Vet Q, 32: 75-86

13- De Geus ED, Vervelde L. (2013). Regulation of macrophage and dendritic cell function by pathogens and through immunomodulation in the avian mucosa. Dev Comp Immunol., 41: $341-351$

14- Diker S. (2005). İmmunoloji. Ankara, Medisan

15- Dursun N. edt. (2006). Evcil Kuşların Anatomisi. Ankara, Medisan.

16- Fagerland JA. (1992). The role of bronchus-associated lymphoid tissue in respiratory immunity of chickens and turkey: morphologic and functional studies. [https://lib.driastate. edu/rtd]

17- Fagerland JA, Arp LH. (1993). Structure and development of bronchus-associated lymphoid tissue in chickens. Avian Dis, 37: 8-10.

18- Fagerland JA, Arp LH. (1993). Distribution and quantitation of plasma cells, T lymphocyte subsets, and B lymphocytes in bronchus-associated lymphoid tissue of chickens: Agerelated differences. Reg. Immunol, 5: 28-36

19- Fan X, Liu S, Liu G, Zhao J, Jiao H, Wang X, Son Z. (2015). Vitamin A deficiency impairs mucin expression and suppresses the mucosal immune function of the respiratory tractin chicks. PloS One, 10: e0139131.

20- Fix AS, Arp LH. (1989). Conjunctiva associated lymphoid tissue (CALT) in normal and Bordetella avium infected turkeys. Vet Pathol, 26: 222-230

21- Fix AS, Arp LH. (1991). Morphologic characterization of conjunctiva associated lymphoid tissue (CALT) in chickens. Am J Vet Res.

22- Gaunson JE, Philip C, Whithear KG, Browning GF. (2000). Lymphocytic infiltration in the chicken trachea in response to Mycoplasma gallisepticum infection. Microbiology, 146: 1223-1229

23- Gayet R, Bioley G, Rochereau N, Paul S, Corthesy B. (2017). Vaccination aganist Salmonella infection: the mucosal way. Microbiol Mol Biol Rev, 81:e00007-17

24- Gurjar RS. (2013). Cell mediated immunity after ocular Arktype infectious bronchitis virus vaccination. [http://hdl.handle.net/10415/35379]

25- Javed MA, Frasca S, JR, Rood D, Cecchini K, Gladd M, Geary SJ, Silbart LK. (2005). Correlates of immune protection in chickens vaccinated with Mycoplasma gallisepticum strain GT5 fol- lowing challenge with pathogenic M. gallisepticum strain $\mathrm{R}$ (low). Infect Immun, 73: 5410-5419.

26- Jawale CV, Lee JH. (2014). An immunogenic Salmonella ghost confers protection against internal organ colonization and egg contamination. Vet Immunol Immunopathol, 162: 41-50

27- Johnston CE, Hartley C, Salisbury AM, Wigley P. (2012). Immunological Changes at Point-of-Lay Increase Susceptibility to Salmonella enterica Serovar Enteritidis Infection in Vccinated Chickens. Plos One, 7: e48195.

28- Kaiser P. (2010). Advances in avian immunology-prospects for disease control: a review. Avian Pathol., 39: 309-324

29- Kaiser P. (2012). The long view: a bright, a brighter future? Forty years of chicken immunology pre-and post-genome. Avian Pathol., 41: 511-518

30- Kang H, Yan M, Yu Q, Yang Q. (2013). Characteristics of nasalassociated lymphoid tissue (NALT) and nasal absorption capacity in chicken. PloS One, 8: e84097.

31- Kang H, Yan M, Yu Q, Yang Q. (2014). Characterization of nasal cavity-associated lymphoid tissue in ducks. Anal Rec, 297: 916-924

32- Khan MZ, Hashımoto Y, Konno A, Kon Y, Iwanaga T. (1996). Development of T-lymphocyte subpopulations in the postnatal chicken oviduct. Cell Tissue Res, 284: 317-325.

33- Kimijima T, Hashımoto $Y$, Kitagawa $H$, Kon $Y$, Sugimura $M$ (1990). Localization of immunoglobulins in the chicken oviduct. Nihon Juigaku Zasshi, 52: 299-305.

34- Kitagawa H, Hosokawa M, Takeuchi T, Yokoyama T, Imagawa T, Uehara M. (2003). The cellular differentiation of $M$ cells from crypt undifferentiated epithelial cells into microvillous epithelial cells in follicle-associated epithelia of chicken cecal tonsils. J. Vet. 35- Med, 65: 171-178.

35- Kimura S. (2018). Molecular insights into the mechanisms of $\mathrm{M}$-cell differentiation and transcytosis in the mucosa-associated lymphoid tissues. Anat Sci Int, 93: 23-34

36- Kozlu T, Altunay H. (2010). Harder Bezi'nin yapısı ve fonksiyonları. Atatürk Üniversitesi Vet. Bil. Derg, 5: 89-96

37- Kozuka Y, Nasu T, Murakami T, Yasuda M. (2010). Comparative studies on the secondary lymphoid tissue areas in the chicken bursa of Fabricius and calf ileal Peyer's patch. Vet Immunol Immunopathol., 133: 190-197

38- Krunkosky M, Garcia M, Garza LG, Karpuzoglu BE, Levin J, Williams RJ, Gogal JR RM. (2018). Seeding of the mucosal leukocytes in the HALT and trachea of White Leghorn chickens. $J$ Immunoassay Immunochem, 39: 43-57.

39- Kumar S, Chen $C$, Indugu N, Werlang GO, Singh M, Kim WK Thippareddi H. (2018). Effect of antibiotic withdrawal in feed on chicken gut microbial dynamics, immunity, growth performance and prevalence of foodborne pathogens. Plos One 13: e0192450

40- Kunisawa J, Kurashima Y, Kiyono H. (2012). Gut-associated lymphoid tissues for the development of oral vaccines: $A d v$ Drug Deliv Rev., 64: 523-530.

41- Lamichhane A, Azegami T, Kiyono H. (2014). The mucosal immune system for vaccine development. Vaccine, 32.

42- Liu YJ, Johnson GD, Gordon J, Maclennan ICM. (1992). Germinal centres in T-cell-dependent antibody responses. Immunol Today, 13: 17-21

43- Lillehoj HS, Lillehoj EP. (2000). Avian Coccidiosis. A review of acquired intestinal immunity and vaccination strategies. Avian Dis., 44: 408-425.

44- Lillehoj HS, Trout JM. (1996). Avian gut-associated lymphoid tissues and intestinal immune responses to Eimeria parasites. Clin Microbiol Rev., 349-360. 
45- Maslak DM. (1994). Head-associated lymphoid tissue [HALT] of the chicken: Characterization of lymphocytes: lowa State Universty.

46- Mutua MP, Muya S, Gicheru MM. (2016). Protective roles of free avian respiratory macrophages in captive birds. Biological Research, 49: 29.

47- Nagy N, Olah I. (2007). Ploric tonsil as a novel gut-associated lymphoepithelial organ of the chicken. J. Anat, 211: 407-411

48- Nii T, Isobe N, Yoshimura Y. (2015). The effect of estrogen on the early cytotoxic response to IB virus infection in hen oviduct. Vet Immunol Immunopathol, 164: 56-66.

49- Nochi T, Jansen CA, Toyomizu M, Van Eden W. (2018). The well-developed mucosal immune systems of birds and mammals allow for similar approaches of mucosal vaccination in both types of animals. Front Nutr, 5: 60 .

50- Ohshima K, Hiramatsu K. (2000). Distribution of T-cell subsets and immunoglobulin-containing cells in nasal-associated lymphoid tissue (NALT) of chickens. Histol Histopathol, 15: 713-720.

51- Ohshima K, Hiramatsu K. (2002). Immunohistochemical localization of three different immunoglobulin classes in the Harderian gland of young chickens. Tissue \& Cell, 34: 129133.

52- Olah I, Scott T, Gallego M, Kendall C, Glick B. (1992). Plasma Cells Expressing Immunoglobulins $\mathrm{M}$ and $\mathrm{A}$ but Immunoglobulin G Develop an Intimate Relationship with Central Canal Epithelium in the Harderian Gland of the Chicken. Poult Sci. 71: 664676

53- Pavot V, Rochereau N, Genin C, Verrier B, Paul S. (2012). New insights in mucosal vaccine development. Vaccine, 30: 142154

54- Qin T, Yin Y, Wang X, Liu H, Lin J, Yu Q, Yang Q. (2015). Whole inactivated Avian Influenza H9N2 viruses induce nasal submucosal dendritic cells to sample luminal viruses via transepithelial dendrites and trigger subsequent DC maturation. Vaccine, 33: 1382-1392.

55- Rauw F, Nguyen T, Ngabirano E, Marche S, Lambrecht B. (2017). Specific antibody-mediated immunity in the reproductive tract of laying chickens immunized against Newcastle disease with conventional attenuated and inactivated vaccines. Avian Pathol, 46: 434-441.

56- Reese S, Dalamani G, Kaspers B. (2006).The avian lung-associated immune system: A review. Vet. Res, 37: 311-324.

57- Saatçi F, Bozkır A. (2003). Aşıların nazal yoldan uygulanışı: Ankara Ecz. Fak. Derg., 3: 32

58- Sepahi A, Salinas I. (2016). The evolution of nasal immune systems in vertebrates. Molecular Immunology, 69: 131-138.
59- Shakya AK, Chowdhury MYE, Tao W, Gill HS. (2016). Mucosal vaccine delivery: Current state and a pediatric perspective. $J$ Control Release, 240: 394-413.

60- Shira E, Friedman A. (2018). Innate immune functions of avian intestinal epithelial cells: Response to bacterial stimuli and localization of responding cells in the developing avian digestive tract. PLOS ONE, 13: e0200393.

61- Smialek M, Tykalowski B, Stenzel T, Koncicki A. (2011). Local immunity of the respiratory mucosal system in chickens and turkeys. Polish J Vet Sci, 14: 291-297

62- Tamura S-I, Kurata T. (2004). Defense mechanisms against influenza virus infection in the respiratory tract mucosa. Jpn. J. Infect. Dis, 57: 236-247.

63- Van Ginkel F, Gulley S, Lammers A, Hoerr F, Gurjar R, Toro H. (2012). Conjunctiva-associated lymphoid tissue in avian mucosal immunity. Dev Comp Immunol., 36: 289-297.

64- Wang J, Tang C, Wang Q, Li R, Chen Z, Han X, Wang J, Xu $X$. (2015). Apoptosis induction and release of inflammatory cytokines in the oviduct of egg-laying hens experimentally infected with H9N2 avian influenza virus. Vet. Microbiol, 177: 302-314.

65- Wigley P, Hulme SD, Powers C, Beal RK, Berchieri A, JR, Smith A, Barrow P. (2005). Infection of the Reproductive Tract and Eggs with Salmonella enterica Serovar Pullorum in the Chicken Is Associated with Suppression of Cellular Immunity at Sexual Maturity. Infect Immun, 73: 2986-299

66- Withanage GS, Sasai K, Fukata T, Miyamoto T, Lillehoj HS Baba E. (2003). Increased lymphocyte subpopulations and macrophages in the ovaries and oviducts of laying hens infected with Salmonella enterica serovar Enteritidis. 32: 583590

67- Withanage G, Baba E, Sasai K, Fukata T, Kuwamura M, Miyamoto T, Arakawa A. (1997). Localization and Enumeration of T and B Lymphocytes in the Reproductive Tract of Laying Hens. Poult Sci., 76: 671-676.

68- Yılmaz H, Mutuş R, Minbay A. (1995). Tavuklarda plazma hücrelerinin immunoperoksidaz yöntemi ile belirlenmesi ve lenfoid dokulardaki lokalizasyonu. İstanbul Ünv. Vet. Fak. Derg., 1: 282-294

69- Yoshimura Y. (2015). Avian Beta-defensins expression for the innate immune system in hen reproductive organs. Poult Sci. 94: 804-809.

70- Zhao K, Rong G, Hao Y, Yu L, Kang H, Wang X, Wang X, Jin Z, Ren Z, Li Z. (2016). IgA response and protection following nasal vaccination of chickens with Newcastle disease virus DNA vaccine nanoencapsulated with $\mathrm{Ag} @ \mathrm{SiO} 2$ hollow nanoparticles. Sci Rep., 6: 25720/ DOI:10.1038/srep25720. 